Jurdimas (Jurnal Pengabdian Kepada Masyarakat) Royal

Vol. 5 No. 1, Januari 2022, hlm. 85 - 92

ISSN 2614-7912 (Print)

DOI: https://doi.org/10.33330/jurdimas.v5i1.1232

ISSN 2622-3813 (Online)

Available online at https:/jurnal.stmikroyal.ac.id/index.php/jurdimas

\title{
PARTISIPASI MASYARAKAT DALAM PENATAAN RUANG TERBUKA HIJAU DI KELURAHAN GUNUNG ANYAR SURABAYA
}

\author{
Nira Zhahfirah Puspitasari ${ }^{1}$, Novia Dia Kumala ${ }^{1}$, Yoga Raffi Krisnanda Putra ${ }^{1}$, \\ Syifa Syarifah Alamiyah ${ }^{{ }^{*}}$ \\ ${ }^{1}$ Program Studi Ilmu Komunikasi, Universitas Pembangunan Nasional Veteran Jawa Timur \\ Email: *syifa_syarifah.ilkom@upnjatim.ac.id
}

\begin{abstract}
Reforestation is reforestation of forests that have been barren or barren with the aim of improving the quality of the environment. This reforestation was carried out in the Mud Volcano area, Gunung Anyar village, Surabaya. This study aims to describe community participation in the implementation of the Green Open Space Reforestation (RTH) program in Gunung Anyar, Gunung Anyar Village, Surabaya City and the obstacles faced. This study uses a descriptive method with a qualitative approach where data collection is done by observation, in-depth interviews with informants, and documentation studies. The results of this study indicate that there is a community called Griyo Maos. Griyo Maos is a community that is active in social activities such as establishing a free reading park and contributing to the maintenance of Green Open Space in the Gunung Mud Volcano area in Gunung Anyar, Surabaya. The Griyo Maos community has made a major contribution to caring for and protecting the environment in the Gunung Anyar mud volcano area. In this study, there were 3 stages that were passed, namely the preparation, implementation, and evaluation stages. Based on these 3 stages, the participation of the community represented by Griyo Maos is considered to have contributed optimally to the implementation of the Green Open Space Reforestation program, while the surrounding community is still less contributing to these activities.
\end{abstract}

Keywords: green open space; reforestation; mud volcano

Abstrak: Reboisasi yaitu penghijauan kembali hutan yang sudah gundul atau tandus yang bertujuan untuk meningkatkan kualitas lingkungan hidup. Reboisasi ini dilaksanakan pada wilayah Mud Volcano kelurahan Gunung Anyar Surabaya. Penelitian ini bertujuan untuk mendeskripsikan partisipasi masyarakat dalam pelaksanaan program Reboisasi Ruang Terbuka Hijau (RTH) di Gunung Anyar, Kelurahan Gunung Anyar, Kota Surabaya dan kendala yang dihadapi. Penelitian ini menggunakan metode deskriptif dengan pendekatan kualitatif dimana pengumpulan data dilakukan dengan observasi, wawancara mendalam dengan informan, dan studi dokumentasi. Hasil penelitian ini menunjukkan bahwa terdapat sebuah komunitas yang bernama Griyo Maos. Griyo Maos merupakan suatu komunitas yang aktif dalam kegiatan sosial seperti mendirikan taman baca secara gratis dan berkontribusi dalam pemeliharaan Ruang Terbuka Hijau di kawasan Gunung Mud Volcano yang berada di Gunung Anyar, Surabaya. Komunitas Griyo Maos ini memiliki kontribusi besar untuk merawat dan menjaga lingkungan di kawasan mud volcano Gunung Anyar tersebut. Dalam penelitian ini terdapat 3 tahapan yang dilalui yaitu tahap persiapan, pelaksanaan, dan juga evaluasi. Berdasarkan 3 tahapan tersebut maka partisipasi masyarakat yang di representasikan oleh Griyo Maos dinilai telah berkontribusi secara optimal dalam pelaksanaan program Reboisasi Ruang Terbuka Hijau, sementara itu masyarakat sekitar masih kurang berkontribusi dalam kegiatan tersebut.

Kata kunci: gunung lumpur; reboisasi; ruang terbuka hijau 
Jurdimas (Jurnal Pengabdian Kepada Masyarakat) Royal

Vol. 5 No. 1, Januari 2022, hlm. 85 - 92

ISSN 2614-7912 (Print)

DOI: https://doi.org/10.33330/jurdimas.v5i1.1232

ISSN 2622-3813 (Online)

Available online at https:/jurnal.stmikroyal.ac.id/index.php/jurdimas

\section{PENDAHULUAN}

Ruang Terbuka Hijau (RTH) sangat diperlukan dalam menjaga keseimbangan kualitas lingkungan hidup di suatu perkotaan salah satunya dengan melakukan reboisasi. Reboisasi perlu digalakkan kembali agar kelestarian lingkungan dan juga habitat bagi hewan serta tumbuh-tumbuhan dapat terjaga dan juga guna menyadarkan masyarakat tentang pentingnya menjaga lingkungan sekitar. (Putri, Soemardiono, \& Suprihardjo, 2017) Menjelaskan bahwa yang dimaksud Ruang Terbuka Hijau (RTH) merupakan suatu tempat atau suatu permukaan lahan yang jenis tumbuhannya kebanyakan memiliki fungsi melindungi ekosistem atau area khusus yang dimaksud dan Ruang Terbuka Hijau juga mempunyai fungsi untuk meningkatkan dan menjaga kualitas udara serta berguna juga untuk mengurangi polusi udara. Tujuan dari adanya Ruang Terbuka Hijau adalah untuk menjaga keindahan suatu kawasan hijau serta menjaga ekosistem agar keseimbangannya tetap terjaga yang diharapkan sebagai upaya untuk pelestarian ekosistem, meminimalisir terjadinya banjir, sebagai penyaring udara kotor, dan membuat daerah sekitar terlihat lebih sejuk. Reboisasi yaitu penghijauan kembali hutan yang sudah gundul atau tandus yang bertujuan untuk mening-katkan kualitas lingkungan hidup. Reboisasi ini dilaksanakan pada wilayah Mud Volcano (gunung api lumpur) kelurahan Gunung Anyar terkenal sebagai salah satu kota metropolitan padat penduduk dan gedung pencakar langit, siapa sangka Surabaya ini juga mempunyai gunung. Mud volcano gunung anyar ini sejenis dengan mud volcano yang berada di porong pada 2007 silam meluber dan menelan seluruh kampung yang berada dikawasan tersebut.

Mud volcano gunung anyar ini memiliki tinggi 3,5 meter dan memiliki perbedaan yang mencolok dengan mud volcano lainnya. Hingga saat ini gunung tersebut masih aktif mengeluarkan lumpur dan berada tepat di tengah-tengah pemukiman warga. Sudah ratusan tahun warga sekitar hidup berdampingan dengan mud volcano gunung anyar tersebut. Kondisi mud volcano gunung anyar tersebut sejatinya sama dengan Lumpur Lapindo yang berada di Sidoarjo, hanya saja mud volcano yang berada di Gunung Anyar tersebut merupakan versi minimalisnya dan masih belum tersentuh oleh Industri, sementara Lumpur Lapindo sudah. Maka dari itu akan sangat berbahaya apabila terdapat cara penanganan yang salah kepada Gunung tersebut, karena dikhawatirkan semburan lumpur yang ada volumenya akan semakin tinggi dan akan membanjiri permukiman yang ada disana, dan akan sangat mungkin apabila bencana Lumpur seperti di Sidoarjo akan terulang kembali di Surabaya. Karena memiliki kesadaran akan pentingnya menjaga kelestarian lingkungan, beberapa pemuda yang tergabung dalam komunitas griyo maos gunung anyar bersama warga sekitar turut andil dalam memelihara dan merawat kawasan mud volcano yang berada di gunung anyar.

Pemerintah memiliki beberapa rencana kegiatan untuk menjaga alam sekitar. Salah satunya adalah Gerakan Nasional Rehabilitasi Hutan dan Lahan (GNRHL). Program tersebut tertera pada Peraturan Pemerintah Republik Indonesia Nomor 76 Tahun 2008 Tentang Rehabilitasi dan Reklamasi Hutan. Tujuan dari Peraturan Pemerintah tersebut adalah melaksanakan program reboisasi. Oleh karena itu pelaksanaan reboisasi Ruang 
Available online at https:/jurnal.stmikroyal.ac.id/index.php/jurdimas

Terbuka Hijau (RTH) di kawasan mud volcano gunung anyar dapat dimulai dari partisipasi masyarakat yang turut andil dalam pemeliharaan tersebut. Ada beberapa program yang dibuat oleh komunitas yang bernama "griyo maos" berupa mendirikan taman baca secara gratis dan pemeliharaan Ruang Terbuka Hijau Mud Volcano seperti membersihkan serta menanami berbagai macam jenis tanaman di kawasan tersebut. Program penanaman berbagai jenis tanaman merupakan proses penataan Ruang Terbuka Hijau (RTH), warga sekitar mempunyai gagasan berupa mengajak masyarakat untuk melaksanakan kerja bakti yang bertujuan merekondisi serta memelihara kelestarian lingkungan dalam upaya reboisasi Ruang Terbuka Hijau (RTH).

$$
\text { Dalam upaya reboisasi }
$$

diharapkan dapat diikuti oleh seluruh warga sekitar yang dinilai kurang berkontribusi dalam kegiatan sosial di kawasan tersebut, karena masih terdapat warga sekitar yang kurang sadar akan pentingnya menjaga kelestarian lingkungan dengan membuang sampah sembarangan di kawasan tersebut, masih ada masyarakat yang nakal mengambil tumbuhan endemik seperti kaktus yang nantinya akan dijual kembali dan juga terdapat masyarakat yang mementingkan kepentingan pribadi sehingga tidak terlibat dalam upaya reboisasi Ruang Terbuka Hijau (RTH). (Ngongare, Rompas, \& Kiyai, 2019) menjelaskan bahwa partisipasi masyarakat dalam sebuah pembangunan merupakan kegiatan keikutsertaan masyarakat dalam suatu pembangunan, serta mengikuti kegiatan dalam pembangunan dan pemanfaatan serta menikmati hasil dari pembangunan tersebut. Partisipasi masyarakat bertujuan agar setiap individu mempunyai perannya masing-masing dalam kegiatan yang diselenggarakan untuk mengembangkan daerah mereka, lalu dengan adanya peran tersebut diharapkan masyarakat dapat menyalurkan ide, inovasi, maupun suatu inisiasi dalam pengembangan daerah mereka dengan penuh tanggung jawab dalam menjalaninya. Dalam berjalannya suatu program terdapat faktor-faktor penunjang dan penghambat partisipasi masyarakat, contoh faktor penunjang adalah keahlian, tekad, dan peluang, sementara faktor yang menghambat partisipasi masyarakat adalah seperti kurangnya wawasan, sikap apatis masyarakat terhadap kegiatan pembangunan yang diselenggarakan, dan juga pekerjaan yang biasanya menyita banyak waktu sehingga tidak dapat mengikuti kegiatan-kegiatan yang ada. Adanya kedua faktor tersebut dikarenakan adanya bentuk perasaan tingkah laku untuk berbuat sesuatu atau bersikap apatis terhadap lingkungan.

Permasalahan mengenai partisipasi masyarakat dalam program reboisasi ini telah diangkat oleh beberapa peneliti diantaranya (Neto \& Tueno, 2019) dalam penelitiannya menunjukkan bahwa jika dilihat dari faktor pengetahuan masih belum optimal, masyarakat desa di kecamatan Bulango masih banyak memiliki latar belakang pendidikan yang rendah kebanyakan tidak lulus SD serta masyarakat tidak pernah mengikuti pelatihan apapun. Dikarenakan faktor kesadaran masyarakat tani yang masih rendah dan berimbas adanya kelompok tani yang nantinya akan membuka lahan dengan sembarangan sehingga terdapat lahan yang menjadi gersang.

Sementara penelitian lainnya mengenai Partisipasi Masyarakat Dalam Pengembangan Cagar Budaya Sebagai Ruang Publik (Studi Kasus Gedung Balai Pemuda Kota Surabaya). Metode yang 
Available online at https:/jurnal.stmikroyal.ac.id/index.php/jurdimas

digunakan yaitu deskriptif dengan pendekatan kualitatif. Penelitian ini menggambarkan bahwa pengembangan Cagar Budaya Gedung Balai Pemuda Kota Surabaya sebagai Ruang Publik dinilai cukup baik terlihat dari tingkat partisipasi masyarakat yang tergabung dalam komunitas dan juga seniman yang ikut serta dalam mengembangkan cagar budaya tersebut, keikutsertaan mereka seperti kontribusi dalam kegiatan diskusi dan menyumbangkan ide atau gagasan pada pelaksanaan program kegiatan. Masyarakat mendapatkan edukasi tentang kesenian, pendidikan, dan juga kebudayaan. Setelah itu, pada tahap evaluasi pihak yang berwenang adalah Dinas Kebudayaan dan Pariwisata Kota Surabaya dan Unit Pelaksana Teknis Dinas Balai Pemuda. Pada tahap evaluasi ini partisipasi yang diberikan masyarakat yakni hanya sebatas memberikan kritik dan saran (Prabowo \& Ma'ruf, 2016).

Pada penelitian berikutnya yaitu Partisipasi Masyarakat dalam Pengelolaan Ruang Terbuka Hijau Publik di Kecamatan Umbulharjo, Kota Yogyakarta. Dari penelitian tersebut hasil yang didapatkan adalah pada setiap tahapan pengelolaan, masyarakat di empat lokasi yang ada berpartisipasi dalam tahapan tersebut. Contoh kontribusi tersebut berupa berpartisipasi dalam setiap kegiatan yang ada, ide-ide, ketrampilan, harta benda, dan tenaga ditemui pada pengelolaan Ruang Terbuka Hijau di kecamatan Umbulharjo. Bentuk partisipasi masyarakat biasanya didominasi oleh inisiatif pemberian ide atau pemikiran yang akhirnya beberapa dari hasil buah pemikiran tersebut direalisasikan. Beberapa pihak yang berperan aktif berkontribusi di lapangan pada saat penataan ruang terbuka hijau publik di kecamatan Umbulharjo yaitu masyarakat sekitar yang berkontribusi pada tiap tahap pengelolaan(Setiawan \& Widiyastuti, 2018).

(Tandang \& Tembalang, 2008) Karakteristik Ruang Terbuka Hijau (RTH) di daerah pemukiman yaitu sebagai kawasan yang berkembang di atas lahan dengan keragaman tingkat kemiringan. Secara estetika, kondisi lahan yang ada tidak teratur serta kontur tanah sangat beragam dan cenderung bersifat kering dapat mengakibatkan tidak semua jenis tumbuhan tumbuh subur dikarenakan adanya lumpur yang keluar dari gunung yang berada ditangah lahan tersebut.

Karakteristik Ruang Terbuka Hijau sendiri menyesuaikan dengan tipologi kawasannya, berdasarkan (Ruang, 2008) Karakteristik Ruang Terbuka Hijau (RTH) memiliki jenis tipologi kawasan perkotaan meliputi : pertama, pantai yang fungsi utamanya yaitu perlindungan di daerah pantai, sosial budaya setempat, dan meminimalisir risiko bencana di daerah pantai. Penerapan (RTH) menurut luas area serta berdasarkan fungsi tertentu. Kedua, pegunungan yang fungsi utamanya yaitu pemeliharaan tanah, pemeliharaan air, dan keragaman hayati. Penerapan Ruang Terbuka Hijau (RTH) berdasarkan luas wilayah dan berdasarkan luas tertentu. Ketiga, Rawan Bencana yang fungsi utamanya yaitu mitigasi atau evakuasi bencana. Penerapan Ruang Terbuka Hijau (RTH) berdasarkan fungsi tertentu. Keempat, Berpenduduk jarang s.d sedang yang fungsi utamanya yaitu dasar perencanaan kawasan dan sosial. Penerapan kebutuhan Ruang Terbuka Hijau (RTH) berdasarkan fungsi tertentu dan berdasarkan jumlah penduduk. Kelima, berpenduduk padat yang fungsi utamanya yaitu ekologis, social, dan hidrologis. Penerapan kebutuhan Ruang Terbuka Hijau (RTH) berdasarkan fungsi tertentu 
Available online at https:/jurnal.stmikroyal.ac.id/index.php/jurdimas

dan berdasarkan jumlah penduduk.

Manfaat Ruang Terbuka Hijau pertama, dapat menghasilkan Oksigen (O2) yang dipergunakan mahluk hidup untuk bernapas, dan juga tujuan utamanya adalah sebagai paru-paru Kota. Kedua menumbuhkan dan juga menjaga kawasan mikro, vegetasi yang diharapkan menjadi area yang sejuk, nyaman, dan segar. Ketiga, melindungi dan juga sebagai penyeimbang kondisi alam. Keempat, menekan adanya polusi udara, polusi suara, dan juga polusi air. Kelima, untuk menambah keasrian dan keanggunan Kota dan dapat juga dimanfaatkan untuk tempat rekreasi bagi masyarakat(Lubis \& Sulistyarso, 2018). Penelitian ini dibuat dengan tujuan untuk menunjukkan bahwa partisipasi masyarakat dalam upaya reboisasi ruang terbuka hijau yang dilakukan dengan masyarakat di gunung anyar (Griyo Maos) guna melestarikan ruang terbuka hijau di Gunung Anyar, Kelurahan Gunung Anyar, Kota Surabaya

\section{METODE}

Penelitian ini menggunakan
metode penelitian kualitatif yang
bertujuan untuk menjelaskan serta
menganalisis suatu fenomena, atau suatu
peristiwa. Tahap ini meliputi kegiatan
perizinan kepada pihak RT 01, RW 02
kemudian paguyuban pemuda gunung
anyar dan juga kepada komunitas griyo
maos baik meliputi lokasi, waktu, dan
tempat pelaksanaan penelitian. Tahap ini
juga menyangkut beberapa persiapan
bahan yaitu bibit pohon, batu kumbung,
pupuk, air, dan penanam.

Responden dalam penelitian ini meliputi ketua dan juga beberapa anggota dari Griyo Maos. Sebelum melaksanakan kegiatan peneliti dan komunitas griyo maos berdiskusi terkait rancangan program yang akan dijalankan serta mencari penyelesaian yang menguntungkan kedua belah pihak terkait pelaksanaan program yang akan di jalankan. Dalam penelitian ini menggunakan beberapa jenis data yaitu data primer dan sekunder. Data primer itu sendiri pada penelitian ini didapatkan secara langsung dengan cara observasi, wawancara, serta survei lapangan. Penelitian ditujukan kepada seluruh masyarakat sekitar kawasan mud volcano. Terdapat 2 informan penelitian yang dirasa mempunyai kapabilitas dan juga memiliki kredibilitas. Penelitian ini berlangsung selama 2 minggu di sekitar kawasan Ruang Terbuka Hijau (RTH) mud volcano, kelurahan gunung anyar.

Sedangkan data sekunder sendiri kami dapatkan dari beberapa sumber seperti dokumen yang ada serta studi literatur dan juga artikel yang berkaitan dengan ruang terbuka hijau.

\section{PEMBAHASAN}

Dari data primer dan sekunder yang telah kami peroleh dengan cara observasi, survei langsung di Gunung Anyar, Kelurahan Gunung Anyar, Kota Surabaya. serta studi literatur, antara lain: Yang termasuk dalam partisipasi masyarakat ini yaitu seluruh masyarakat sekitar kawasan Ruang Terbuka Hijau mud volcano dan komunitas griyo maos. Griyo Maos yaitu suatu perkumpulan yang terdiri dari masyarakat sekitar yang berfokus untuk melakukan edukasi, seperti pembukaan taman bacaan untuk anak-anak dan memperkenalkan kepada kalangan masyarakat untuk selalu ikut dalam menjaga lingkungan sekitar. Dan juga reboisasi, seperti penanaman berbagai macam bibit pohon produktif 
Jurdimas (Jurnal Pengabdian Kepada Masyarakat) Royal

Vol. 5 No. 1, Januari 2022, hlm. 85 - 92

ISSN 2614-7912 (Print)

DOI: https://doi.org/10.33330/jurdimas.v5i1.1232

ISSN 2622-3813 (Online)

Available online at https:/jurnal.stmikroyal.ac.id/index.php/jurdimas

maupun bibit pohon cemara agar tempat tersebut terlihat sejuk guna meningkatkan kualitas udara dan upaya dalam pembuatan hutan dapat teralisasikan dalam kurun waktu 10-20 tahun mendatang.

\section{Tahapan Pelaksanaan}

Setiap kegiatan pelaksanaan program Reboisasi Ruang Terbuka Hijau (RTH) diharapkan dapat menyalurkan manfaat yang optimal untuk masyarakat sekitar dalam memenuhi kebutuhan. Partisipasi masyarakat Gunung Anyar terhadap pelaksanaan program reboisasi dilakukan secara bersama-sama tidak dibagi atas beberapa kelompok. Keberhasilan suatu proses pelaksanaan berkaitan erat dengan adanya partisipasi masyarakatnya, baik dalam sebuah sistem maupun sebagai individu yang merupakan keseluruhan yang berpengaruh penting dalam menjalankan proses pembangunan guna mewujudkan masyarakat yang sejahtera.

Pelaksanaan program Reboisasi Ruang Terbuka Hijau (RTH) di kawasan mud volcano kelurahan Gunung Anyar ini tetap memperhatikan kondisi masyarakat, lingkungan, dan manfaat dari adanya Program Reboisasi yang di laksanakan, selain itu tidak semua masyarakat dapat berpartisipasi aktif dalam program Reboisasi ini. Sementara itu, pihak yang sebagian besar terlibat dan juga berpartisipasi aktif pada penataan Ruang Terbuka Hijau mud volcano yaitu griyo maos.

Partisipasi masyarakat secara Non fisik atau bersumber dari pemikiran dalam sebuah proses pembangunan masyarakat sekitar bersifat mutlak guna mencapai tujuan tersebut. Upaya menumbuhkan kemampuan masyarakat untuk turut aktif dalam berpartisipasi bertujuan untuk dapat meringankan beban dan menghasilkan pembangunan atas proses pelaksanaan program tersebut dapat dirasa efektif karena program yang akan dilaksanakan sudah terencana secara matang. Dalam kegiatan tersebut, keberhasilan suatu program merupakan tanggung jawab masyarakat. Peran dan partisipasi masyarakat gunung anyar sejauh ini masih kurang peduli dengan lingkungan sekitar, terbukti masih adanya masyarakat yang tidak menjaga kebersihan Ruang Terbuka Hijau (RTH) di kawasan mud volcano dan masih terdapat masyarakat yang mementingkan kepentingan pribadi seperti mengambil tumbuhan endemik di kawasan tersebut yang nantinya akan dijual kembali.

Karena kesadaran itu beberapa pemuda yang tergabung dalam komunitas Griyo Maos Gunung Anyar bersama warga Gunung Anyar berupaya untuk menjaga dan merawatnya. Kegiatan yang dilakukan yaitu pembersihan dan reboisasi di kawasan mud volcano. Kegiatan pembersihan kawasan mud volcano meliputi, membersihkan sampah yang berserakan dan membersihkan rumput liar. Selanjutnya dalam kegiatan reboisasi meliputi, pengambilan bibit pohon cemara secara gratis di kawasan ekowisata mangrove dibawah binaan Dinas Ketahanan Pangan dan Pertanian Kota Surabaya. Dikarenakan bertepatan dengan hari raya idul adha, rekan-rekan griyo maos berinisiatif untuk mengumpulkan fases sapi dari kandang para pedagang hewan kurban di sepanjang jalan Ir. Soekarno. Fases sapi yang hanya dibuang, selanjutnya akan dikumpulkan dalam pembuatan pupuk kandang. Mengingat kawasan mud volcano ini cukup luas, maka pembuatan pupuk secara mandiri merupakan solusi yang tepat untuk memenuhi kebutuhan pupuk di kawasan tersebut. Kemudian dilakukan penanaman beberapa bibit pohon produktif 
Available online at https:/jurnal.stmikroyal.ac.id/index.php/jurdimas

seperti, tomat, terong, jeruk purut, jeruk mandarin, pandan, daun salam, kedondong dan bibit pohon cemara. Serta memberikan edukasi sejak dini akan pentingnya menjaga lingkungan.

Secara garis besar, dalam suksesnya pelaksanaan program Reboisasi Ruang Terbuka Hijau (RTH) menjadi tanggung jawab bersama, dari masyarakat sekitar maupun pemerintah. Lain daripada pemberian sanksi pidana yang berat bagi masyarakat yang tidak dapat mematuhi peraturan. Peraturan tersebut harus tegas agar tidak dipandang sebelah mata. Pemerintah tidak akan bisa bekerja secara optimal jika tidak ada keterlibatan mayarakat. Begitupun masyarakat juga membutuhkan pemerintah sebagai penyelenggara urusan pemerintahan. Adanya penataan Ruang Terbuka Hijau (RTH), pihak masyarakat sekitar akan memperoleh manfaat seperti, bertambahnya kadar oksigen yang digunakan untuk bernapas makhluk hidup, serta diharapkan mengurangi polusi udara yang ada di lingkungan sekitar, rencana pembuatan hutan dalam jangka waktu 10 hingga 20 tahun akan dirasakan manfaatnya oleh masyarakat sekitar.

\section{Tahapan Evaluasi}

Dari kegiatan yang telah peneliti lakukan di lapangan, terdapat beberapa kendala pada saat proses pelaksanaan yaitu, masih kurangnya kesadaran masyarakat akan pentingnya perawatan Ruang Terbuka Hijau (RTH). Apabila masyarakat tidak dilibatkan dalam kegiatan tersebut dikhawatirkan menyebabkan muncul sikap pesimis dari masyarakat sehingga timbul asumsiasumsi bahwa kegiatan reboisasi di Gunung Anyar tersebut hanya untuk kalangan orang-orang tertentu yang ditunjuk oleh aparat pemerintahan
Kelurahan. Dan hal tersebut akhirnya dapat memicu timbulnya ketidakpedulian masyarakat terhadap kegiatan gerakan reboisasi Gunung itu sendiri, serta kebersihan Ruang Terbuka Hijau (RTH) tersebut.Dan yang terakhir, masih rendahnya partisipasi warga sekitar dalam berjalannya proses upaya reboisasi, hal ini mungkin disebabkan sudah terwakilkannya pihak masyarakat sekitar oleh pihak Griyo Maos tersebut, sehingga masyarakat sekitar mungkin percaya hasil-hasil yang diberikan Griyo Maos akan maksimal hasil pekerjaannya.

\section{SIMPULAN}

Partisipasi Masyarakat Dalam Pelaksanaan Program Penataan Ruang Terbuka Hijau Di Kelurahan Gunung Anyar Surabaya yaitu dalam pelaksanaan program reboisasi ruang terbuka hijau tidak akan dapat berjalan dengan baik jika melibatkan satu komponen masyarakat saja. Keterlibatan masyarakat dalam pelaksanaan program ini begitu penting karena partisipasi masyarakat atas kepedulian serta tanggung jawab masyarakat terhadap pentingnya Reboisasi demi meningkatkan kualitas udara disekitar Gunung Anyar. Peran antara pemerintah dan masyarakat dibutukan guna berjalan secara optimal

\section{DAFTAR PUSTAKA}

Hadi, A. P. (2014). Konsep pemberdayaan, partisipasi dan kelembagaan dalam pembangunan. Pusat Pengembangan Masyarakat Agrikarya, 3(2), 1-14.

Lubis, A. R., \& Sulistyarso, H. (2018). Strategi Peningkatan Efektivitas 
Available online at https:/jurnal.stmikroyal.ac.id/index.php/jurdimas

Ruang Terbuka Hijau Di Perumahan Wisma Gunun Anyar Surabaya (Vol. 7). doi: 10.12962/j23373539.v7i1.28924

Neto, F., \& Tueno, N. S. (2019). Faktorfaktor Penghambat Partisipasi Masyarakat dalam Pelaksanaan Program Reboisasi di Kecamatan Bulango Ulu Kabupaten Bone Bolango. Jurnal Manajemen Sumber Daya Manusia, Administrasi Dan Pelayanan Publik, VI(2), 106-114.

Ngongare, A., Rompas, W., \& Kiyai, B. (2019). PARTISIPASI MASYARAKAT DALAM PEMBANGUNANDESA DI DESA HATETABAKO KECAMATAN WASILE TENGAH KABUPATEN HALMAHERA TIMUR. Jurnal Administrasi Publik, 5(73).

Prabowo, D. A., \& Ma'ruf, M. F. (2016). Partisipasi Masyarakat Dalam Pengembangan Cagar Budaya Sebagai Ruang Publik (Studi Kasus Gedung Balai Pemuda Kota Surabaya). Jurnal Publika, 4(11), 1-10.

Prasetyo, K., \& Arif, L. (2021). Civil Society Participation in Efforts to Prevent the Spread. Jurnal Administrasi Publik (Public Administration Journal),
11(June), 22-31. doi: 10.31289/jap.v11i1.4118

Putri, D. G., Soemardiono, B., \& Suprihardjo, R. (2017). Konsep Penataan Ruang Terbuka Hijau Di Kawasan Pusat Kota Ponorogo. Jurnal Penataan Ruang, 7(1). doi: 10.12962/j2716179x.v7i1.2261

Ruang, direktorat jendral penataan departemen pekerjaan umum. Peraturan Menteri Pekerjaan Umum Nomor: 05/PRT/M/2008. , (2008).

Setiawan, A., \& Widiyastuti, D. (2018). Partisipasi Masyarakat dalam Pengelolaan Ruang Terbuka Hijau Publik di Kecamatan Umbulharjo, Kota Yogyakarta. Jurnal Bumi Indonesia, 7(1), 110.

Tandang, D. I. K., \& Tembalang, K. (2008). PADA KAWASAN PERMUKIMAN Oleh :

Peraturan Pemerintah Republik Indonesia Nomor 76 Tahun 2008 Tentang Rehabilitasi Dan Reklamasi Hutan.

Peraturan Pemerintah Nomor 35 Tahun 2002 Tentang Dana Reboisasi

Peraturan Menteri Pu. No. 5/Prt/M/2008 Tentang Pedoman Penyediaan Dan Pemanfaatan Ruang Terbuka Hijau Di Kawasan Perkotaan. 